https://doi.org/10.1590/198053146174

\title{
THE EVALUATION OF PLAY QUALITY IN EARLY CHILDHOOD EDUCATION
}

\author{
Ângela Scalabrin Coutinho' \\ Catarina Moro" \\ Daniele Marques Vieira"' \\ TRANSLATED BY Julián BargueñoIV
}

\begin{abstract}
From the production about the Context Evaluation on Child Education and the research experience in this field, this text presents and discusses a qualitative research about the evaluation of play at a child education institution in Curitiba. It was proposed and realized an internal evaluation course, participatory and formative with the faculty, coordination, direction and pedagogical advice, of an educational institution for children, since babies, from 4 months to 5 years and eleven months. Part of this process was the ad hoc construction of an instrument that served as a support for the reflections and discussions, in group, aiming at "protagonist participation". There was an increase in awareness of the individual and collective perspectives on the play. The collective construction of the instrument from a research process allowed the deepening of concepts related to the theme, consisting of a process of singular continuous formation.
\end{abstract}

\section{EARLY CHILDHOOD EDUCATION • PLAY • QUALITY • EVALUATION}

\section{A AVALIAÇÃO DA QUALIDADE DA BRINCADEIRA NA EDUCAÇÃO INFANTIL}

\section{Resumo}

O presente texto expõe e discute uma investigação qualitativa sobre a avaliação da brincadeira em uma instituição de Educação Infantil de Curitiba. Foi proposto um percurso de avaliação interna, participativo e formativo junto ao corpo docente, coordenação, direção e assessoramento pedagógico de uma instituição educacional para crianças de 4 meses a 6 anos incompletos. Fez parte desse processo a construção ad hoc de um instrumento que deu suporte para as reflexões e discussões em grupo, visando a uma "participação protagônica". Ao final, evidenciou-se a ampliação da consciência das perspectivas individuais e coletivas acerca da brincadeira. A construção coletiva do instrumento a partir de um processo de investigação permitiu o aprofundamento de conceitos ligados ao tema e consistiu em um processo de formação continuada singular.

\section{EDUCAÇÃO INFANTIL • BRINCADEIRA • QUALIDADE • AVALIAÇÃO}

I Universidade Federal do Paraná (UFPR), Curitiba (PR), Brazil; https://orcid.org/0000-0002-3709-8561; angelamscoutinho@gmail.com

II Universidade Federal do Paraná (UFPR), Curitiba (PR), Brazil; https://orcid.org/0000-0003-3109-5885; moro.catarina@gmail.com

III Universidade Federal do Paraná (UFPR), Curitiba (PR), Brazil; https://orcid.org/0000-0001-6866-7053; danielemarquesvieira@gmail.com

IV Freelancer; julianbarg@yahoo.com 


\section{ÉVALUATION DE LA QUALITÉ DES JEUX DANS L'ÉDUCATION PRÉSCOLAIRE \\ Résumé}

Ce texte concerne une enquête qualitative sur l'évaluation des jeux dans un établissement d'éducation préscolaire à Curitiba. Une démarche d'évaluation interne, participative et formative a été proposée au corps enseignant, à la coordination, à la direction et au conseil pédagogique d'un établissement d'éducation préscolaire destiné aux enfants de 4 mois à 6 ans. La construction ad hoc d'un instrument s'est inscrite dans le cadre de ce processus, afin de soutenir la réflexion et la discussion du groupe et d'encourager une "participation engagée". Les résultats de cette enquête ont mis en évidence l'élargissement de la prise de conscience des perspectives individuelles et collectives concernant le jeu. La construction collective de cet instrument à partir d'un processus de recherche a permis d'approfondir les concepts liés au thème et de développer un processus singulier de formation continue.

\section{ÉDUCATION DE LA PETITE ENFANCE • JEU • QUALITÉ • ÉVALUATION}

\section{LA EVALUACIÓN DE LA CALIDAD DEL JUEGO EN LA EDUCACIÓN INFANTIL}

\section{Resumen}

Este artículo expone y analiza una investigación cualitativa sobre la evaluación del juego en un centro de Educación Infantil en Curitiba. Se propuso un itinerario de evaluación interna, participativo y formativo con el profesorado, con la coordinación, dirección y con el asesoramiento pedagógico de una institución educativa para niños de 4 meses hasta 6 años. Fue parte de este proceso la construcción ad hoc de un instrumento que apoyó las reflexiones y las discusiones grupales, con el objetivo de una "participación protagonista". Finalmente se demostró la ampliación de la conciencia de las perspectivas individuales y colectivas sobre el juego. La construcción colectiva del instrumento a partir de un proceso de investigación permitió profundizar los conceptos relacionados con el tema y consistió en un proceso de formación continuada singular.

EDUCACIÓN INFANTIL • JUEGO • CALIDAD・EVALUACIÓN 
HE EVAlUATIVE PROCESS, WHICH WE WILL DISCUSS IN THIS ARTICLE, HAS AS PREMISES constituted as self-reflective, negotiating, transformative and participativedemocratic (BONDIOLI; SAVIO, 2013). This means understanding this movement from the engagement of professionals, from a particular institution or educational network, interested in self-evaluating some aspect or dimension of their work for and with children and their families.

In the Brazilian scenario, early childhood education aims to provide conditions and resources for the enjoyment of children's rights, complementing and sharing the competences of families, and expanding the possibilities for good interactions between adults and children and their peers. In addition, it should amplify its access to new acquirements and knowledge, safeguarding childhood experiences in their many diversities. Achieving these goals in the education of children up to 6 years of age implies different dimensions that need to be constantly improved in the educational daily life of institutions. The pedagogical proposal; unit management; the teaching staff and other professionals; the pedagogical coordination services; the relationship with external services; the infrastructure of the spaces; the relational and social environment among professionals; the security; attention in educational situations of hygiene, food and sleep; the proposed educational experiences, involving the languages and other dimensions of the curriculum; the organization of pedagogical work and pedagogical documentation; relationships with families; the opportunities 
and conditions for children to play are examples of a set of aspects that determine the kind of formative experience that the preschool offers to children and their families.

In this sense, from Bondioli (2008) we understand the educational context consisting of concrete elements (people, furniture, materials, etc.) that are composed in the material, relational and symbolic dimensions, articulate and define themselves in a dynamic, reciprocal and continuous way. Taking contextual evaluation for yourself as a collective and collegial assignment means seeking answers to questions that go beyond knowing whether we are doing “our job well or badly". Bondioli (2004) proposes two questions inherent to this self-evaluation movement, to reflect on the work being done: "Why do I do what I do?" And "What, in fact, do I get from what I do?".

With this perspective, we propose, in this article, to discuss an evaluative and formative process developed, since 2017, with the pedagogical team (coordination and teachers) of an early childhood institution, based on the context evaluation proposal. Among the dimensions of the pedagogical work, we chose, in the group, play as the object to be evaluated. We chose to build an ad hoc instrument, involving the entire faculty and school management, to support the observation of educational daily life and collective and shared reflection. We also chose to focus and discuss, in this text, one of the dimensions related to play - the space - and constitutive of the instrument.

\section{PLAY AND EARLY CHILDHOOD EDUCATION}

Playing in relation to early childhood and the provision of education in institutions for young children has long been the subject of debate and research, both nationally and internationally. There are several approaches, both within certain areas of science, with emphasis on Anthropology, Pedagogy, Psychology, Sociology, as well as between the areas.

Children's play is a complex and central issue when it comes to taking into consideration the educational routine and the quality of the experiences offered to children in nurseries and preschools. Many questions arise when there is the intention to contemplate play in educational contexts. For example, we constantly wonder what the meaning of play is for children; which tensions and dimensions go through their play; how to contemplate the play in the educational daily life in kindergartens and preschools so that they are good experiences for the children.

Documents dealing with children's rights and labor guidelines in educational contexts, whose age ranges from birth to 6 years old, also focus on issues related to play. The 1989 United Nations (UN) Convention recognizes the right of children to play in its Art. 31. Also the Statute of the Child and Adolescent of 1990, updated with Law No. 13.257 of 2016, deals, in Chapter II, (with) “The Right to Freedom, Respect and Dignity IV - playing, playing sports and having fun; [...]" (BRASIL, 1990). Even before the current Law of Guidelines and Bases of 
National Education (LDBEN), in Law No. 9,9394/1996, published by the Ministry of Education (MEC) entitled Critérios para um atendimento em creches que respeite os direitos fundamentais das crianças" [Criteria for Service to Nurseries that Respects the Fundamental Rights of Children] ${ }^{1}$ (BRAZIL, 1995), play is defended as a fundamental right among the 12 rights presented and discussed in the document.

It is noteworthy that, in this document (BRASIL, 1995), the explicit criteria are indicative to be contemplated in the educational offer in relation to the right of children to play, by proposing that within the early childhood education units we should consider the availability and accessibility of toys to children; organization and care in the packaging of toys and the child's participation in this process; need for long periods for children to experience free play; need to guide family members about the importance of play; organization and use of indoor and outdoor spaces in order to propose and encourage spontaneous and interactive play; importance of the participation of adults (teachers) in children's play, proposing new games, helping them with unfamiliar toys; the importance of children engaging in distinct and non-gendered play.

In order to achieve the above aspects and their intent, the policies and programs of early childhood education need to provide budget for the purchase and replacement of toys, other materials and furniture, considering the number of children attended and the age groups; professionals in proportion compatible with the promotion of interactive and playful situations; in-service training that recognizes and values play in the child's educational path. Also, when new buildings are being built, it is essential to predict the demand for good structural conditions for indoor and outdoor play. These are some parameters that can certainly be added, or better detailed, in order to reaffirm and incorporate children's right to play in the educational daily life of early childhood institutions.

More recently, in 2009, the text of the National Curriculum Guidelines for Early Childhood Education (DCNEI) (BRASIL, 2009), recognized the importance of the status of play, considered together with interactions, guiding axis of the pedagogical work to be planned and effective in educational institutions. By conceiving the institution of early childhood education as a locus of formation and expansion of the cultural repertoires of children (and their families) and understanding them as social, cultural, historical and rights subjects, playing is a central element of pedagogical action. Numerous challenges arise when starting from this understanding to organize pedagogical work, starting with the very concept of play.

According to Spréa (2010, p. 225, own translation), “play is a place of creative and continuous effort, in which participants have to collectively organize themselves in order to combine experiences not yet known" ${ }^{2}$. Such experiences

1 http://portal.mec.gov.br/dmdocuments/direitosfundamentais.pdf

2 In the original: "brincadeira é um lugar de esforço criativo e contínuo, em que os participantes têm que se organizar coletivamente, de modo a conjugar experiências ainda não conhecidas". 
provide the confrontation of children's interests, the consensus on rule-making, the involvement in creative complicity. This understanding is related to William Corsaro's (2002) conception of interpretive reproduction in children's makebelieve play. According to the author, Children collectively produce a culture of peers that has as characteristic the reproduction of the adult worlds, but not only, "children are creatively appropriating information from the adult world, to produce their own culture of peers" (p.114), that is, children are social actors who actively participate in their socialization processes by producing culture through play with their peers.

Also in 2009, MEC published the Indicadores da Qualidade na Educação Infantil [Quality Indicators in Early Childhood Education] (BRASIL, 2009a), in which, considering the play and its educational offer as a children's right, proposes a self-reflection about how institutions have corresponded to this right and a selfevaluation of this process. Thus, questions about playing in the institutional environment of nurseries and preschools are present in different parts of the instrument in articulation with four (4) of the seven (7) dimensions that constitute it (planning, multiplicity of experiences and languages, interactions and spaces, materials and furniture).

Among the references of evaluation tools for educational spaces for children and infants, we can mention the Infant/Toddler Environment Rating Scale (ITERs-R) and Early Childhood Environment Rating Scale (ECERs-R), prepared by US researchers, as well as the Quality Improvement and Accreditation System (QIAS) ${ }^{3}$, produced by the Australian National Day Care Accreditation Council and used for research in Brazil (CAMPOS et al., 2011; SOUZA, CAMPOS-DE-CARVALHO, 2005; ZUCOLOTO, 2011; PIOTTO et al., 1998) and, still, Avaluació de centres d'educació infantil (ACEI) (DARDER; MESTRES, 2000), not used in Brazil. These instruments are examples of evaluation of early childhood education that also include indicators related to play and toys as part of investigations into the quality of everyday pedagogical work.

Regarding a specific instrument on the evaluation of play, Savio (2013a, 2011) conducted an action research with the network of nurseries in Modena, Italy, rooted in the formative context evaluation approach, as proposed by Bondioli and Ferrari (2004), Bondioli and Savio (2013), Bondioli (2015) and Savio (2013b) and based on an initial and main question for that group at that time: "What, or what conditions are best for children's play?".

\section{THE QUALITY OF THE LUDIC OFFER IN VIEW OF THE CONTEXT EVALUATION}

Recognition of play as crucial for children's well-being and growth, according to Savio (2013a, p. 257, own translation), "predicts the child's active participation 
and indicates play as an authentic 'voice' of childhood, the main instrument to be able to realize it" ${ }^{4}$ The author also states that one of the main reasons why Modena nurseries put play in the foreground was the fact that the educators considered that this activity had been neglected in recent training courses and that it was necessary to reaffirm play as a central element of the educational relationship (SAVIO, 2013a, 2011), so it was important to specify the playful quality of nurseries in that context.

Savio resorted to the context evaluation approach, which, among its distinctive features, stands as formative, participatory, self-reflective and of internal promotion, through "continuous feedback between field action and critical reflection of the experiences, with the intention to standardize the evaluation process and test its effectiveness" ${ }^{5}$ (BONDIOLI; SAVIO, 2015, p. 23, own translation). In methodological terms, this perspective foresees the chain of some steps and actions in the midst of the evaluative path filled with reflexive and business processes. The different stages that we will briefly present (TABLE1) may include "one or more working moments, according to the particular requirements of the specific educational reality considered” (BONDIOLI; SAVIO, 2015, p. 29, own translation).

\section{TABLE 1}

\section{STEPS OF THE METHODOLOGICAL PATH OF CONTEXT EVALUATION}

\begin{tabular}{|c|l|}
\hline PHASES & \multicolumn{1}{|c|}{ ACTIONS } \\
\hline I & $\begin{array}{l}\text { The collective or one of the participants of a given educational institution or network } \\
\text { manifest themselves in the search to effect an evaluative contextual path. It is negotiated } \\
\text { who will participate (actively) in the work group, which depending on the choices may also } \\
\text { consist of family members, technical and political managers, and the professional team of } \\
\text { the educational context to be evaluated. The working group must have a maximum of } 20 \\
\text { participants. With a higher number, the best option is to work in parallel with more than one } \\
\text { group. }\end{array}$ \\
\hline II & $\begin{array}{l}\text { The group or working groups set up specify and negotiate the goals as well as the relevant } \\
\text { aspects in the evaluation path. The goal may be to evaluate the educational institution } \\
\text { as a whole in order to reflect on "what is done and why it is done", as well as to evaluate } \\
\text { elements or aspects, part of the educational offer that is being carried out? in this institution. } \\
\text { This choice is open and can be renegotiated along the way, in order to better reflect on the } \\
\text { educational identity of that reality, looking for improvement projects. }\end{array}$ \\
\hline III & $\begin{array}{l}\text { The group identifies, negotiates, (re)constructs the evaluation instrument to be used to } \\
\text { collect information about the reality/aspect to be evaluated. It is worth considering as a } \\
\text { constitutive part of this stage the critical analysis of the instrument. Each participant of the } \\
\text { evaluation process will explain their agreements and disagreements with the indicative of the } \\
\text { educational quality proposed by the chosen instrument. }\end{array}$ \\
\hline
\end{tabular}

4 In the original: "prevê a participação ativa da criança e indica a brincadeira, como 'voz' autêntica da infância, o instrumento principal para poder realizá-la".

5 In the original: "um feedback contínuo entre ação de campo e reflexão crítica das experiências efetuadas, com a intenção de padronizar o processo avaliativo e de testar sua eficácia".

6 In the original: "com um ou mais momentos de trabalho, segundo as exigências particulares da realidade educativa específica considerada".

7 Bondioli and Savio (2015, p. 30) state that: "In any case, the task always has to do with reflecting on the educational identity of the institution under examination, for example, choosing to evaluate the spaces for the play of the educational context itself means reflecting on its quality in relation to the pedagogical ideas of the participants and, therefore, definitely means reflecting on the individual and group educational identities". [In the original: "Seja como for, a tarefa tem sempre a ver com a reflexão sobre a identidade educativa da instituição em exame, por exemplo, a escolha de avaliar os espaços para a brincadeira do próprio contexto educativo significa refletir sobre sua qualidade em relação às ideias pedagógicas dos participantes e, portanto, definitivamente, significa refletir sobre as identidades educativas individuais e do próprio grupo".] 


\begin{tabular}{|c|l|}
\hline PHASES & \multicolumn{1}{c|}{ ACTIONS } \\
\hline IV & $\begin{array}{l}\text { Realization of the evaluation itself, through the observation of the educational routine using } \\
\text { the chosen instrument, as well as making use of other data collection strategies - consultation } \\
\text { of documents, interviews and others. This step is done individually. The time will be common } \\
\text { for each participant, for example one week, to observe reality compared to what is described } \\
\text { in the instrument, assigning the quality criteria or describing the quality found and assigning } \\
\text { the corresponding scores. }\end{array}$ \\
\hline V & $\begin{array}{l}\text { Reflection stage on the records and individual evaluation data, prepared and given back to } \\
\text { the group by the mediator, with particular attention to aspects that emerge as "strengths" or } \\
\text { "weaknesses", and the eventual evaluation differences, even negotiating a profile, at least in } \\
\text { part, shared, of the educational identity of the institution itself. }\end{array}$ \\
\hline VI & $\begin{array}{l}\text { Negotiation and decision making about the implementation of an improvement project, based } \\
\text { on the discussion of data collected by the group. }\end{array}$ \\
\hline VII & $\begin{array}{l}\text { As a final (even partial) conclusion of the process, it is important to evaluate the evaluative } \\
\text { path taken. This action reaffirms the formative potentiality of the whole process. }\end{array}$ \\
\hline
\end{tabular}

Source: Prepared by the authors based on Bondioli and Savio (2015) and Coutinho, Moro and Souza (2015).

For the proper progress of the methodological procedures of this evaluative approach, the presence and role of the external mediator/evaluator is essential.

Methodologically, [the mediator] has the responsibility of the entire course and its fulfillment, which translates into the task of facilitating the triggering of reflection, debate and negotiation processes, but also of the true and proper evaluation process, which requires the use of the instruments in which he/she specializes. [...] personally calls the participants into question; uses a language and proposes congruent connections with the educational perspectives that emerge from the group; maintains direction towards the accomplishment of the shared task; provokes to stimulate the clarification of latent pedagogies; contains the frustration caused by discovering educational weaknesses and differences of opinion; shows how to reflect deeply and to negotiate, explaining meanings only perceived by the participants, besides making possible connections between different points of view. By activating these functions, he/she retains a different but equal role in relation to the "peer" group: he/she has competence in the method, but not in the investigated educational identity, of which the only specialists are the professional educators who make up the working group. Moreover, he/she is neutral, open and curious about any expressed viewpoint. ${ }^{8}$ (BONDIOLI; SAVIO, 2015, p. 32, own translation)

8 In the original: "Metodologicamente, [o formador] tem a responsabilidade de todo o percurso e do seu cumprimento, que se traduz na tarefa de facilitar o desencadeamento dos processos de reflexão, debate e negociação, mas também do processo de avaliação verdadeiro e próprio, que exige o uso dos instrumentos nos quais é especialista. [...] chama em causa pessoalmente os participantes; utiliza uma linguagem e propõe conexões congruentes com as perspectivas educativas que emergem do grupo; mantém a direção visando à realização da tarefa compartilhada; provoca para estimular a explicitação de pedagogias latentes; contém a frustração provocada por descobrir fragilidades educativas e diferenças de opiniões; mostra como se faz para refletir em profundidade e para negociar, explicitando significados somente intuídos pelos participantes, além de fazer conexões possíveis entre diversos pontos de vista. Ao ativar tais funções, mantém um papel diferente, mas paritário em relação ao grupo dos "pares": tem competência no método, mas não na identidade educativa investigada, da qual os únicos especialistas são os profissionais educadores que compõem o grupo de trabalho. Além disso, é neutro, aberto e curioso em relação a qualquer ponto de vista expresso." 
Through studies in the Brazilian reality, Coutinho, Moro and Souza (2015, p. 63) vehemently explained how challenging the role of the mediator along an evaluative contextual pathway is. This role implies a parity role, since the external evaluator/mediator is expert in relation to the evaluation process methodology, while the participants in the evaluated context - internal evaluators - are the specialists in that educational reality.

The methodology of this approach requires the external mediator/ evaluator to raise "questions so that the other's point of view reveals latent conceptions and ideas" without judging from another's point of view, expressing authentic curiosity and openness to listening. From this perspective, Savio (2013a, 2011), as a mediator in her action research, invited the teachers to reflect on the subject, wondering what conditions would be demanded by the children for their play and, in a broader sense, to their well-being. Such movement in the collective represents an effort of participation to debate and share the different points of view about the "voice of the child", that is, about understanding their needs, curiosities, concerns and convictions expressed in children's play.

The evaluative process experienced in Modena involved several meetings, in which eighty-eight (88) professionals were involved in twelve (12) of the eighteen (18) municipal nurseries and four (4) of the twenty-four (24) accredited nurseries, separated in two groups. It was based on a questionnaire applied individually about the importance of play in early childhood and nursery; then there were meetings to draw up the first draft instrument and to discuss this draft and then turn it into a more complete version (SAVIO, 2013a, 2011). In these meetings, it was discussed the importance of giving voice to the child in the play in different ludic contexts, reaching a consensus to acquire a common vocabulary for the various types of play and agreeing on a criteria to establish the concept of the construction of the "good ludic nursery". For Savio, the quality criteria established in the instrument is due to the fact that the observation of the child's play is used to "reveal the competences, the interests, the ludic needs, and to take them as reference in the planning and evaluation of the various dimensions of context that refer to play"' (SAVIO, 2013a, p. 277, own translation).

Inspired by this experience, especially from the participatory perspective adopted, we developed research to evaluate the quality of play in an early childhood education institution. Following, we present this research, its stages and the choices made to evaluate the quality of play. In the following part, we unveil aspects about the investigative-formative process, and, as a result, we expose an analysis of what teachers think about play by the dimension of space. We conclude with considerations to broaden the dialogue on the proposed theme.

9 In the original: "revelar as competências, os interesses, as necessidades lúdicas, e a tomá-los como referência no planejamento e avaliação das várias dimensões de contexto que se referem à brincadeira". 


\section{THE RESEARCH-FORMATION: PROCESS, CHOICES AND LIVED STAGES}

In the context of the continuing education of the early childhood education institution participating in this study, early in the 2017 school year, during the Pedagogical Week, with the presence of all staff - managers, educators, teachers and external mediators - with the purpose of fostering reflection on the principles governing the institution's pedagogical political project and the axes of work in early childhood education, there was a need to deepen our understanding of social relations and play in the constitution of children from 4 months to 6 years old. At the time, the team consisted of twelve (12) teachers, one (1) pedagogical coordinator, two (2) principals, one (1) pedagogical advisor and one (1) external r; and in 2018 the group was added with three (3) teachers and one (1) pedagogical coordinator, totaling twenty-one (21) participants.

Initially, we proposed that teachers observe daily moments in the period between February and the first half of March, focusing on aspects related to Social Relations, questioning how children establish and constitute their relationships in the context of early childhood education; with whom they relate; who are the others in the relationship; how professional adults can enhance children's relationships with each other; how and if we have contemplated relationships in planning. Aspects related to Play were also questioned, starting from questions such as: What do our children play? What repertoires are revealed in your play? How are they organized? What is the function of the materialities and repertoires presented? What is the relationship with time? Where are the adults?

Seeking greater approximation to the ways in which children build their relationships in the educational context, it was proposed that each teacher from the different groups or classes of the $\mathrm{school}^{10}$, chose an observed situation to describe and relate to the contents of the texts chosen and indicated for study (SARMENTO; 2004; FERREIRA, 2004; BRASIL, 2015). These choices should emphasize: a) Children's cultures and their constitutive aspects: common elements that can be observed in the productions of children's cultures, aspects that mark the uniqueness of a given culture, such as the institution; b) play as a complex experience that involves body, language and play routines, seeking to understand this experience for children and the role of adults, in view of their direct participation in the modes of play organization (FERREIRA, 2004) and an indication of aspects to be considered about play when the focus is the educational experience within the institution of early childhood education (BRASIL, 2015).

Based on this exercise, the institution's pedagogical team (management ${ }^{11}$ and coordination) selected 3 records for shared analysis, when it was discussed with the external mediator the purpose of the record - relationships and effectiveness

10 At the time there were the following groupings at the school: G1 - 4 months to 2 years old; $\mathrm{G} 2$ - 2 to 3 years old; G3 - 3 to 4 years old; G4 - 4 to 5 years old; G5 - 5 to 6 years old

11 The pedagogical advisor proposes to the team - pedagogical management and coordination - the continuing education program, fulfilling the role of mediator of the training processes that have the participation of collaborators - external mediators. 
as a resource for the study of play. Reflecting on the reports from the proposition of shared analysis, three (3) criteria were defined for the organization of the process: description of the educational situation in focus; theoretical-practical relationship and reflection.

From this debate, the focus of continuing education was defined as the ad hoc elaboration of an instrument to assess play in the daily life of the institution. As the formative process continued, it was realized that the most pertinent perspective for assessing play would be through Context Evaluation. Thus, the group studied the material produced from the national research "Formation of the Network in Early Childhood Education: Context Avaluation” (BRASIL, 2015; SOUZA; MORO; COUTINHO, 2015) and the text "Children's Play and Participation: an Educational Challenge and its Nodal Points" - about Donatella Savio's research on the "good ludic nursery" and Modena's experience, to think about play in the daily life of early childhood education (SAVIO, 2013a, 2011).

The intention was to build a path of appreciation, knowledge and evaluation of the quality of play in the institution, focusing on: i. Study about play; ii. Observation of children and their play; iii. Development of an evaluation instrument. In order to problematize the reference used for this study, the starting question was: “Can we start from Modena's experience, in which play was taken from the perspective of child participation, to think about play in our context?".

In this sense, the constant task of turning to observe play in the institution was to allow ourselves to look at each situation as an opportunity to think about the aspects of play that go through us as experience; and what we are able to hear from children. From this discussion, a Concept Map was prepared (Figure 1) that resulted from a construction of the collective of teachers, pedagogues, managers and pedagogical advisor:

\section{FIGURE 1}

CONCEPTUAL MAP ON EARLY CHILDHOOD PLAY

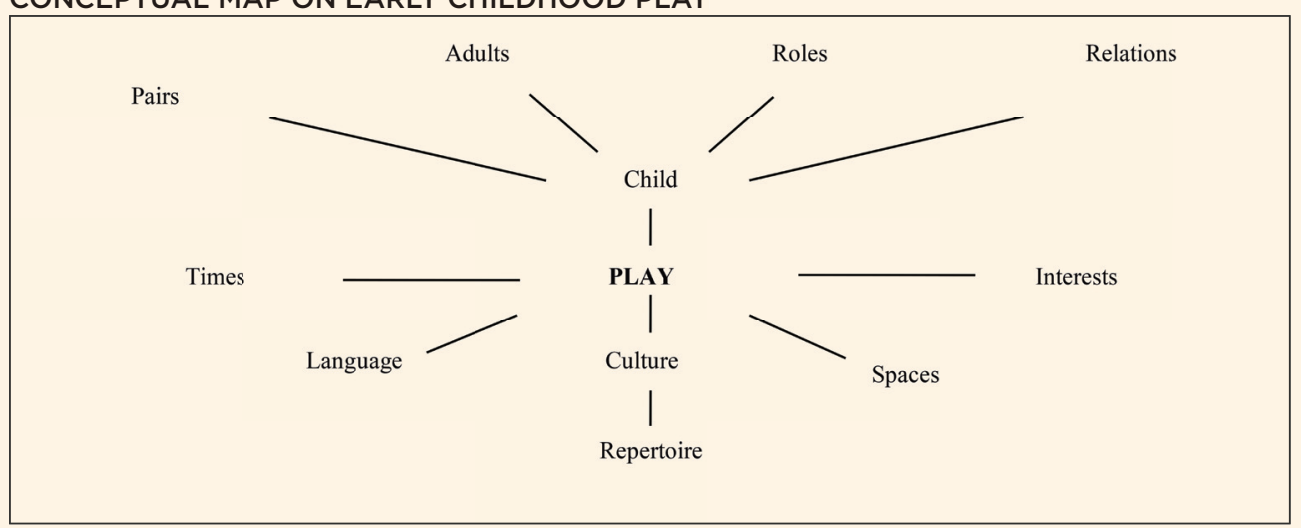

Source: Prepared from data provided by the early childhood institution. 
Continuing the understanding of play and the construction of a common idea that could constitute the reference for collective evaluation, followed with a reflective exercise based on the following propositions or questions:

1. Think of the child's play and describe the first image that comes to mind.

2. What role do you think play plays in early childhood?

3. What do you think are the characteristics of a "good nursery" in relation to children's play?

Subsequently, it was proposed to discuss indicators relevant to the construction of an instrument. Through the answers, the mediator resented diverse understandings about the meaning of play, explained by the teachers, and then systematized, which provided a negotiated dialogue in order to conclude a definition of the Play axis, the result of the collective discussion of the institution's professionals.

Play is one of the axes of the school, happens at different times of daily life and permeates different languages, to ensure the conditions for the involvement of children in permanent and flexible contexts, so that they can interact with themselves, with each other and in groups of different ages. Play is a social action of choice for the child, which he/ she does seriously. Through play, the child organizes his/her thinking and builds culture, while through it, extrapolates reality, fantasy and establishes relationships between what is real and what is imaginary, expanding his/her understanding of the world. Play is the ultimate expression of what it is to be a child, an opportunity that allows them to learn about themselves through the perception of the body in the construction of their identity; it delineates space and time to the senses that make the child protagonist; it provides bonds; it forms pairs; it consolidates meanings; and it favors the establishment of relationships with the other, the physical environment and objects. (INSTITUIÇÃO DE EDUCAÇÃO INFANTIL, 2017)

Once configured this definition of Play, built by the collective, quality criteria were discussed for its implementation in daily practice, whose purpose was the full experience of children. The definition of these criteria occurred from the comparison between the indications of the studies carried out in the formative process with the pedagogical project of the institution, the goal was to have them as a starting point to elaborate evaluation items that considered the specificities of the context to be evaluated.

It is worth noting that the process of constructing the evaluation instrument was organized by the organization of small groups of teachers, based 
on the approximation of the age of their reference groups, which addressed the indicators of the evaluation instrument "good ludic nursery" (SAVIO, 2011), to discuss what each point implied. The teachers also discussed what was proper to the institution, considering the physical space, cultural marks, pedagogical choices and related them to the studied instrument. From this movement resulted the following dimensions: 1) Relationships; 2) Times; 3) Space; 4) Materials; 5) Repertoires; and 6) Languages - in their corresponding items.

Before using the instrument in its entirety, we proposed to start in 2018 with the Space dimension (Table 2). The choice was made because of the space is the dimension that allows the appreciation of context by direct observation of its constituent elements and for the relevance of space in the pedagogical proposal of the school (ZABALZA, 2002; VIÑAO-FRAGO; ESCOLANO, 1998; VIEIRA, 2016).

\section{TABLE 2}

SPACE DIMENSION, PART OF THE PLAY QUALITY EVALUATION INSTRUMENT IN EARLY CHILDHOOD EDUCATION, FIRST VERSION

\begin{tabular}{|l|}
\hline \multicolumn{1}{|c|}{ DIMENSION 3: SPACE } \\
\hline FIRST VERSION \\
\hline 3.1 Does space provide enchantment and curiosity? \\
\hline 3.2 Does space organization invite play? \\
\hline 3.3 Are different spatial configurations guaranteed for repertoire expansion? \\
\hline 3.4 Does space favor the formation of bonds and interactions (between pairs; with objects; with adults)? \\
\hline 3.5 Are spaces delimited to favor play (between pairs; with objects; with adults)? How? \\
\hline 3.6 Can children access materials in space independently? \\
\hline 3.7 Does space cause body challenge games? \\
\hline 3.8 In space are there environments or objects that offer continuity of play? \\
\hline 3.9 What contexts or spaces do we provide for children to experience different social roles? \\
\hline 3.10 What plays are recurring? Internal spaces; External spaces; Others: \\
\hline
\end{tabular}

Source: Instrument for the Evaluation of Play Quality in Early Childhood Education, elaborated by the staff of the early childhood institution.

From this perspective, each group elected a place of the institution organized for play (inside and outside the reference rooms of each group) and performed more than one observation of the children from the items of the instrument. After this stage, a collegiate and transparent discussion meeting on the observation records was held. By making all the records public in the Working Group with the teachers, we noticed the great difference between them - very objective answers appeared, which were restricted to answering directly the instrument items and other more detailed ones, that presented more elements to guide later reflections.

In the item "Does space favor the formation of bonds and interactions (between pairs, objects and adults)?”, two teachers answered as follows: ${ }^{12}$ 
Yes. I could see that there was an interaction between Bento and Téo while playing with the balls. ${ }^{13}$ (Teacher 4)

Yes. Through the observation of how Maria "cared"/played with the doll, Ana, who loves dolls, was watching her. As well as the relationship between Maria and Francisco, while shaking the rattle, looking at each other and inviting themselves to play this game. In addition to the relationship established during a hula hoop play between Maria and Francisco and Ana (who prefers to relate to adults) with Yara. And the relationship between the children of $G 1$ and G2 ${ }^{14}$ through the glass door. ${ }^{15}$ (Teacher 2)

The presentation of the answers for each item of the instrument allowed the teachers to confront their records and become aware that the way they recorded the observed events implied more or less possibilities for reflection.

The characteristics of the answers tend to vary significantly when the choice for the constitution of the instrument is for open qualitative responses. In this sense, the teachers pointed out that, on the one hand, having this kind of item proposal and answer is interesting because it allows exercise something that is central in teaching, observing and registering; but, on the other hand, if the question does not require a more detailed description, some may make use of the instrument quite succinctly, greatly restricting the detail of the answer to the explicit questions. Presenting the answer only as yes or no would be possible, although it does not satisfy the objective of using the instrument, which had already been widely discussed in the group, but depending on the motivation of the observer, short and evasive answers may arise.

To advance in this aspect identified by the group, the external mediator resumed the proposition of the exercise to answer three questions about the items that made up the instrument and, in this case, the Space dimension: its relevance; need to delete or rewrite; need to add new item. This exercise had been proposed at the very beginning of the use of the instrument, because even though it was developed by the same group of teachers, only its use could possibly identify its limits and potentialities, which in fact occurred. However, the teachers initially focused on the registration of the data requested by the items. And the perception of their limits was manifested as they had difficulty identifying or registering what was requested, without an initial concern to also register the limits in the formulation of the items.

13 In the original: "Sim. Pude perceber que houve uma interação, entre Bento e Téo, enquanto brincavam com as bolas."

$14 \mathrm{G} 1$ refers to the class of children who were in the observed space and G2 refers to the class of children who occupied another space, these spaces being divided by a glass door.

15 In the original: "Sim. Através da observação de como a Maria "cuidava"/brincava com a boneca a Ana, que adora bonecas, ficou observando-a. Assim como a relação entre Maria e Francisco, ao agitarem o chocalho, olharem-se e convidarem-se a esta brincadeira. Além da relação estabelecida durante uma brincadeira com bambolês entre Maria e Francisco e a Ana (que prefere relacionar-se com adultos) com a Yara. E a relação entre as crianças do G1 e do G2 pela porta de vidro." 
This process occurred between one discussion meeting and another, and the teachers' appreciation allowed the items to be reworked, making them more appropriate to the observation and registration process. From this perspective, in identifying what could be removed, teacher 3 suggests:

Questions that the possible answers are just "yes" or "no". I consider that this type of question does not raise reflections on the observed context, but closes the questions, for example, item 3.1 says: Does space provide enchantment and curiosity? Probably the answer will be simplistic, without stressing aspects of space, play, enchantment and curiosity itself. ${ }^{16}$ (Teacher 3)

The development of the discussion and analysis of the instrument allowed the teachers participating in the evaluation process to wonder about how much this movement actually allowed to problematize reality to the point of reflecting on it and advancing the improvement of its quality. Thus, as a result of the process, at that time, we came to a new configuration of the instrument, which, for the Space Dimension, was characterized as we see in Table 3:

\section{TABLE 3}

SPACE DIMENSION, PART OF THE PLAY QUALITY EVALUATION INSTRUMENT IN EARLY CHILDHOOD EDUCATION, FINAL VERSION

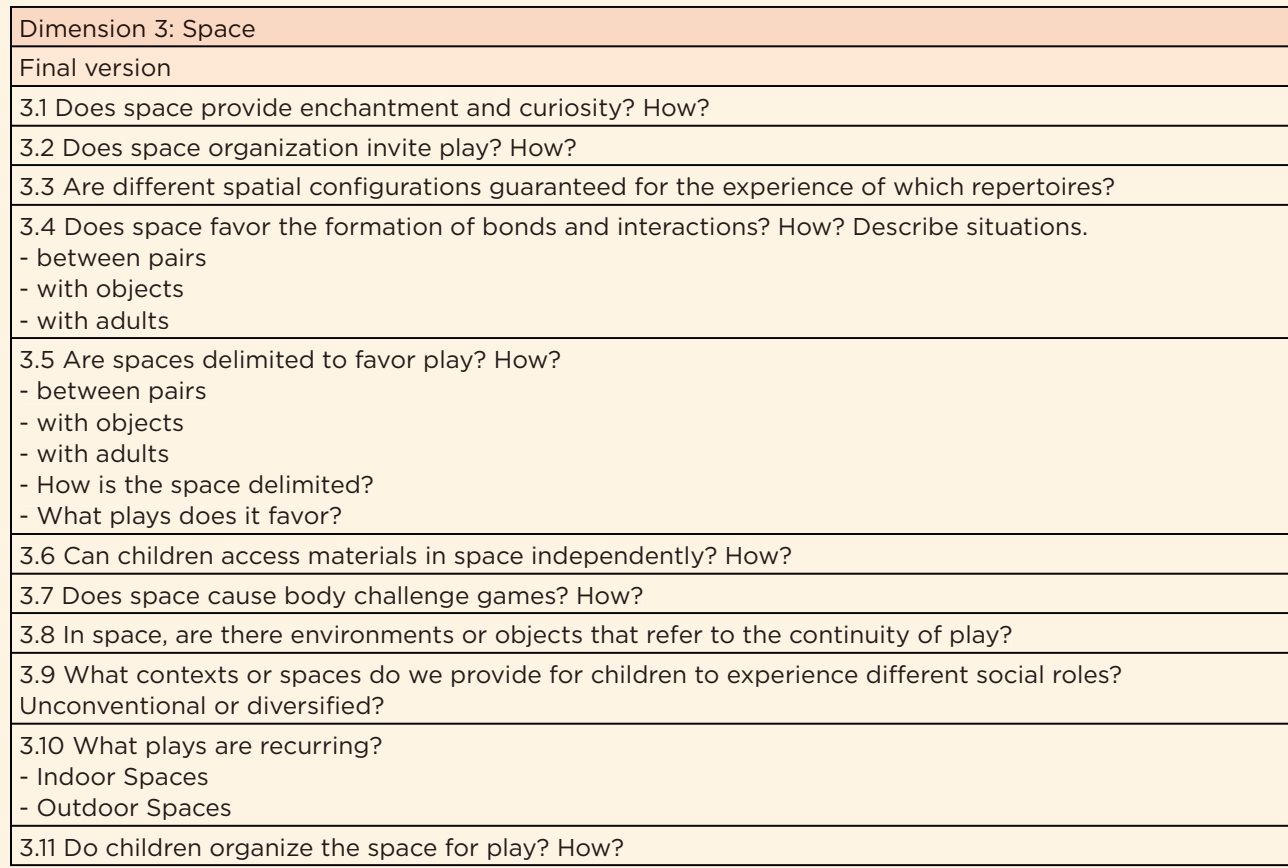

Source: Instrument for the Evaluation of Play Quality in Early Childhood Education, elaborated by the staff of the early childhood institution.

16 In the original: "Perguntas que as possíveis respostas sejam apenas "sim" ou "não". Considero que esse tipo de pergunta não suscita reflexões sobre o contexto observado, mas fecha as questões, por exemplo, o item 3.1 diz: O espaço proporciona encantamento e curiosidade? Provavelmente a resposta será simplista, sem tensionar aspectos do espaço, da brincadeira, do encantamento e da própria curiosidade." 
Throughout 2018, the use of the instrument aimed to guide the educational process and the organization of the teachers' pedagogical work in the institution17. This proposition considered that the evaluation process is always a bet whose subjects involved decide to be involved, or not; that the relationship of the subjects with this evaluation process is what determines its effectiveness; and that this attitude of co-involvement is one of the principles of the context evaluative approach.

The process described, and under analysis, reveals a movement that was built with the effective participation of teachers, who pointed to the need to deepen the approach to play in a context of early childhood education and accepted the proposal to undertake such a process of study and problematization of everyday experiences through context evaluation. It is precisely in this sense that Bondioli (2013, 2004) refers to the evaluation process as potentially formative, from the perspective of educating and transforming those who participate in it by giving them resources, awareness tools, self-determination, a sense of responsibility and professional capacity. The author asserts that: “The scope is also to make people more autonomous, more responsible, better able to make meditated choices, stronger and more solid in their own convictions and orientations" (BONDIOLI, 2013, p. 38).

Collectively building an instrument of reflection required dialogue, confrontation, planning, attempts, which made the process organic and real. Elaborating puts us in the process, causes more questions to emerge, a more arduous path, but which generates "authorship" belonging and produces knowledge. ${ }^{18}$ (Teacher 1)

In this process, collegiate and "protagonist" participation is imperative (MORO; COUTINHO; BARBOSA, 2017, p. 37, own translation) "which calls for a collective to act together, discussing, reflecting and identifying the common objectives intended"; recognizing "the importance of the intertwining of collective and personal experience" 19 . We find in Cussianovish (2005, p. 18) the reference on "protagonist participation" as an exercise of "expression, development and deepening of the collective and personal experience of becoming a protagonist in the exercise of citizenship at all levels of society and people's life". It is important to emphasize that "protagonist participation" in this process of self-reflection and discussion about educational practices needs to "be promoted and assured and,

17 For 2019 we anticipate the finalization of the evaluation making all dimensions with the reevaluation of the instrument as a whole.

18 In the original: "Construir coletivamente um instrumento de reflexão demandou diálogo, confrontos, planejamento, tentativas, o que fez do processo orgânico e real. Elaborar nos coloca dentro do processo, faz com que mais perguntas surjam, um caminho mais árduo, mas que gera pertencimento "autoria" e produz conhecimentos."

19 In the original: "que convoca um coletivo a agir conjuntamente, discutindo, refletindo e identificando os objetivos comuns pretendidos [...] reconhecendo "a importância do entrelaçamento da experiência coletiva e pessoal". 
even if desired, does not mean that implementing it is an easy task" 20 (MORO; COUTINHO; BARBOSA, 2017, p. 37, own translation).

As participants in the evaluation process, the teachers face elements that were not evident from the beginning, which leads to the reaffirmation of the choice of participation by becoming aware of the aspects involved, including the meaning of self-evaluation of the practices. and confronting one's point of view with that of peers. This awareness-making movement has paradoxical consequences, because while promoting a set of discoveries about something that seemed known and proves to be a novelty, it also creates nuisance, given that confrontation and dissent are central elements of the context evaluation methodology, is not something "welcomed, easily accepted" in our training spaces.

The strategy we have chosen to hold a long discussion about what would need to be revised in the wording of the items and the option to consider all the points presented and at the end a small group to synthesize the proposals and translate them into the instrument's rewrite can seem, at first glance, "unproductive". However, even considering the time spent and even often the feeling of a job in circles, it was considered that keeping it was crucial with respect to participatory democratic principle of valuation context, where the role of teachers is a core principle.

In the context of discussion of the observations made by professionals, we highlight two points that directly affect the quality of the process and the perspective of transformation of reality based on negotiated quality. The first, mentioned earlier, refers to the requirement of the subjects' participation, which oscillated throughout the process, requiring the mediators to keep alive their role of promoting the participation of all, encouraging speech, the presentation of the points of view of each one and provoking a reflection on how much the process depended on the manifestation of who constituted the group. At the end of one of the meetings, we evaluated the process, in order to hear from the teachers if it was in the group's interest to maintain the discussion and formation meetings or to finish them. In the teachers' speech, the desire to continue the process was highlighted, however, they indicated how new the dynamics were for them and that the observations, records and reflections added to the already extensive demands of teaching with young children.

\footnotetext{
Implications surrounding the application of the instrument are the organization of materials, time, weather, concern for the children who will be with the helper, if the helper will come, if she will be alone, if the group of children will be successful, etc. ${ }^{21}$ (Teacher 5)
}

20 In the original: "ser promovida e assegurada e ainda que seja desejada não significa que implementá-la seja tarefa fácil".

21 In the original: "As implicações que envolvem a aplicação do instrumento são a organização dos materiais, tempo, clima, a preocupação com as crianças que ficarão com a auxiliar, se a auxiliar virá, se auxiliar ficará sozinha, se o grupo de crianças dará certo, etc." 
This manifestation of the teachers made us realize that context evaluation is not yet understood as a constitutive activity of early childhood education and that its insertion will require the establishment of a path that takes into consideration the characteristics of each context and the necessary reconstruction of the conception of evaluation, in the sense of taking it as an activity that makes up the pedagogical and institutional work and is not external to it. Another necessary change of conception is to understand that context evaluation does not focus on the classification of institutions as good or bad, but seeks to contribute to the internal reflection, identifying what is going well and what deserves attention from the subjects involved in the evaluated experiences, towards quality improvement. From this perspective, it is important to reaffirm that "participating and negotiating quality are sides of the same coin" (BONDIOLI, 2013, p. 34).

The second highlight is the identification of topics that require theoretical deepening. In the excerpt brought to this article, referring to the Space dimension, in two items doubts arose at the moment of observation and, in the group discussion, it became evident the need for an in-depth study on what such themes meant and implied in the practice with the children. Both items had the following statement: "3.3 Are different spatial configurations guaranteed for repertoire expansion?”; “3.8 In the space, are there environments or objects that offer continuity of play?". In discussing the answers given to the items, in addition to the need for revision of the writing, the teachers pointed out the difficulty of identifying what it really meant to "expand repertoires" and "the continuity of play". Thus, after intense debate they concluded that it would be necessary to resume the discussion at another time, seeking a theoretical deepening of these themes and about the "protagonism" (of children), a term widely used in the records and discussions in the group.

The movement of the group in order to problematize the understanding of the themes from different points of view and indicate the need for theoretical deepening around the issues raised reiterates the highly highlighted formative character of Bondioli and Savio (2013) when referring to the "internal promotion", because it was through the decentralization of their action and the exchange of ideas and points of view of each one that the teachers were able to think about dimensions that on the day to day are present, but are little problematized, precisely because of the dynamics of pedagogical work. It also allows us to consider the conditions for a quality early childhood education to be effective, in which times and spaces for study in the collective are sine qua non.

\section{THE EVALUATION OF PLAY AND THE VISIBILITY OF CHILDREN'S ACTIONS}

The process presented and analyzed here was also an opportunity to produce data on children's actions, observed and related to teachers' understanding of what play is, given as the axis of this evaluation process. The possibility of observing 
the little ones and their ways of relating, through the eyes of the other, provoked the group to think about how the game is characterized when the word does not predominate, insurging gesture and other languages.

With the evaluation from the use of the instrument I began to look more carefully at the children's plays and what we offer. Watching with other eyes the way children play. ${ }^{22}$ (Teacher 4)

Understanding the record as a construction of an adult narrative about play, we selected items from the instrument used by G1 teachers that involve babies and very young children, which reveal a perspective present in different perspectives on a common space - Movement Room - whose groups of children of different ages - from 7 months to 1 year and 10 months old - experienced situations which the teachers meant as play. The first item to highlight is "Are different spatial configurations guaranteed for repertoire expansion?", whose answers suggest understandings about the play by the teachers, which are recurrent in other answers.

Yes. The space was organized with elements that provide body movement, explorations and experiments with baskets, sensory bottles, balls, rattles, hula hoops, swimming noodles and dolls and strollers inviting for the symbolic game. ${ }^{23}$ (Teacher 2 , our emphasis)

The words highlighted in the record of Teacher 2 - movement, exploration and experimentation, symbolic play - also appear in the records of other teachers, sometimes explicitly, sometimes implicitly, by detailing the observed actions. As mentioned above, by Teacher 2, regarding the item "Does space favor the formation of bonds and interactions?", which is also evident in the record made by Teacher 3:

Yes. Elisa and Isadora were playing of taking care of the babies with the dolls [symbolic game], Elisa came to bring me a doll to play with both [symbolic game], Isadora took a sensory bottle and offered me water [symbolic game], at another time Tadeu and Isadora enter the box and ask me

\footnotetext{
22 In the original: "Com a avaliação a partir do uso do instrumento passei a olhar de uma forma mais criteriosa as brincadeiras das crianças e o que oferecemos. Observando com outros olhos a maneira que as crianças brincam."

23 In the original: "Sim. O espaço foi organizado com elementos que proporcionam movimentação corporal, explorações e experimentações com cestas, garrafas sensoriais, bolas, chocalhos, bambolês, macarrão para natação e bonecas e carrinhos convidando ao jogo simbólico."
} 
The identification of modes of interaction - movement, exploration and experimentation, symbolic play - as a reference to ways of playing, allows us to think that teachers signal the perception of different actions of babies and very young children in their relationship with the environment, by mastering and specializing the action to the execution of a relativized purpose as play. The observation of what babies and very young children do in these moments that we characterize as play also constitute an immeasurable field of investigation, which the present analysis only suggests as a possibility and allows for deepening and criticism, as also shown in the Teacher 2 statement.

The instrument allowed me to refine and deepen the look on children's play and allowed me to think about the relationships that exist from it. It made me build knowledge about the practice and enrich research on the interests of the group. ${ }^{25}$ (Teacher 2)

Thus, in addition to the process experienced in the field institution of this research-intervention regarding the production of a context evaluation instrument on play, which in itself proves to be striking as an investigation, the meaning of play, expressed in the instrument, by the teachers of babies and very young children, implies constant process of collective debate and study to strengthen an interpretative perspective of the evaluation of play, given its imminently cultural dimension.

\begin{abstract}
As a pedagogue, I observe that the main impact of this instrument on my pedagogical practice was the qualification of the dialogue with the teachers. From the instrument, they have elements for discussion in meetings, just as I could establish relationships with the collective due to the observations and reflections of teachers. ${ }^{26}$ (Pedagogical Coordinator 2)
\end{abstract}

24 In the original: "Sim. A Elisa e a Isadora estavam brincando de cuidar dos bebês com as bonecas [jogo simbólico], a Elisa veio me trazer uma boneca para brincar com as duas [jogo simbólico], Isadora pegou uma garrafa sensorial e me ofereceu água [jogo simbólico], em outro momento Tadeu e Isadora entram na caixa e pedem para que eu puxe a caixa de papelão como uma brincadeira recorrente do pátio coberto [movimentação]."

25 In the original: "O instrumento me permitiu refinar e aprofundar o olhar sobre o brincar das crianças e me possibilitou pensar as relações que existem a partir dele. Me fez construir saberes sobre a prática e enriquecer a investigação sobre os interesses do grupo."

26 In the original: "Como pedagoga, observo que o principal impacto deste instrumento na minha prática pedagógica foi a qualificação do diálogo com as professoras. A partir do instrumento, elas passaram a ter elementos para discussão nas reuniões, assim como eu pude estabelecer relações com o coletivo devido às observações e reflexões de professoras." 
With this statement from the pedagogical coordinator, and from what was evaluated in the Working Group, a perspective of continuity is evident, the possibility of investigation of the concepts identified by the teachers during the evaluation process as pressing for the study of play. Given that they imply an understanding of the role of the adults in offering opportunities thought from the observations, requiring a greater refinement of the perception of children's actions, interpretation and correlation according to other observed moments of play and other moments of use of the instrument, so as to ensure a systematic process of training and quality improvement.

\section{CONSIDERATIONS FOR BROADENING DIALOGUES}

For the field institution of this intervention research, the use of an evaluative instrument was something new, so the whole process, from appropriating what it means to evaluate the context, knowing an instrument that would be taken as base, elaborating its own instrument, using it, discussing the results, evaluating and discussing its structuring, reusing it, discussing the results, planning study themes and quality improvement actions, was an intense and rich formative process, confirming Bondioli's (2004) finding that a participative and formative context evaluation process is capable of educating and transforming the subjects who are engaged in it, contributing to the constitution of their professionality.

The intervention research process analyzed allowed us to problematize some pertinent elements of the context evaluation and, more specifically, when it turns to play in early childhood education. The first point of note is the fact that in order to advance the protagonism of the teachers, it is necessary to ensure continuous and systematic processes of participation, aiming in fact "a protagonist participation in which the actions of the participants have influence in the context". It was evidenced in the process carried out the expansion of the awareness about participation in the collective, about how and why to participate and about the individual perspectives regarding play, through sharing and exchange of ideas in the group. The experience of participation required and allowed each one to make a commitment to the common interests of the group, in an investigative and dynamic stance, negotiating different points of view in order to achieve the desired goals, which differs from deciding what the majority opts for, but from what the group, having heard the different voices, understood as an educational quality.

In this sense, understanding about play and the qualification of their experience in the institution was the motto of the evaluation, but from it the professionals had the opportunity to deepen the conception of playing in early childhood education, refine their ability to observe and record children's experiences, confront the specificities of play for different age groups, exercise authorship, through the elaboration of an evaluation instrument that needed to translate the conceptions elaborated by the collective and, consistent with the unit's proposal and reconstitute their educational practices. regarding ludic 
offers, considering the particularities, the interests of the children and the specificities of each group.

As for the specificities of the age groups, it is noteworthy that the group of professionals decided to develop a single instrument to evaluate the entire institution, ranging from 4 months to 6 years old, and such a choice allowed teachers to identify the marks of play present among babies and very young children - movement, exploration and experimentation, symbolic play - both through recurrence of actions and shared improvement with other subjects - peers and reference adults. The exercise of elaboration of the items, observation, registration and discussion made them recognize play as an element of culture that crosses the experiences of children, since babies, and that the use of an instrument to evaluate the context about how play is opportunized, implies intentionality in the approach and commitment to the collective, which discusses, negotiates and elaborates a conception of quality (BONDIOLI, 2013).

\section{REFERENCES}

BONDIOLI, Anna. "Promuovere dall'interno": un'estensione dell'approccio del "valutare, riflettere, restituire”. In: BONDIOLI, Anna; SAVIO, Donatella (org.). La valutazione di contesto nei servizi per l'infanzia italiani: riflessioni ed esperienze. Parma: Junior-Spaggiari, 2015, p. 25-49.

BONDIOLI, Anna. Construir compartilhando a qualidade: a contribuição das partes interessadas. In: BONDIOLI, Anna; SAVIO, Donatella. Participação e qualidade em educação da infância: percursos de compartilhamento reflexivo em contextos educativos. Curitiba: Editora da UFPR, 2013. p. 25-49.

BONDIOLI, Anna. L'AVSI e la sua “filosofia”. In: BONDIOLI, Anna; FERRARI, Monica (org.). AVSI: Autovalutazione della Scuola dell'Infanzia: uno strumento di formazione e il suo collaudo. Azzano San Paolo (Bg): Edizioni Junior, 2008, p. 13-55.

BONDIOLI, Anna. Valutare. In: BONDIOLI, Anna.; FERRARI, Monica (org.). Verso un modello di valutazione formativa. Azzano San Paolo (Bg): Edizioni Junior, 2004. p. 11-58.

BONDIOLI, Anna; SAVIO, Donatella (org.). Verso un modello di valutazione formativa. Azzano San Paolo (Bg): Edizioni Junior, 2004.

BONDIOLI, Anna; SAVIO, Donatella. Elaborar indicadores de qualidade educativa das instituições de educação infantil: uma pesquisa compartilhada entre Itália e Brasil. In: SOUZA, Gizele de; MORO, Catarina; COUTINHO, Ângela Scalabrin (org.). Formação da rede em educação infantil: avaliação de contexto. Curitiba: Appris, 2015. p. 21-49.

BONDIOLI, Anna; SAVIO, Donatella. Participação e qualidade em educação da infância: percursos de compartilhamento reflexivo em contextos educativos. Curitiba: Editora da UFPR, 2013.

BRASIL. Ministério da Educação. Secretaria de Educação Básica. Coordenação Geral de Educação Infantil. Contribuições para a Política Nacional: a avaliação em educação infantil a partir da avaliação de contexto. Curitiba: Imprensa/UFPR; Brasília, DF: MEC/SEB/COEDI, 2015.

BRASIL. Conselho Nacional de Educação. Câmara da Educação Básica. Resolução CNE/CEB n. 05, de 28 de maio de 2009. Fixa as Diretrizes Curriculares Nacionais para a Educação Infantil. Brasília, 2009a.

BRASIL. Ministério da Educação. Secretaria de Educação Básica. Coordenação Geral de Educação Infantil. Indicadores da qualidade na educação infantil. Brasília: MEC/SEB/COEDI, 2009b. 
BRASIL. Critérios para um atendimento em creches que respeite os direitos fundamentais das crianças. Brasília: MEC/ SEF/ COEDI, 1995.

BRASIL. Estatuto da Criança e do Adolescente. Lei n. 8.069, de 13 de julho de 1990. Brasília, 1990.

CAMPOS, Maria Malta et al. A qualidade da educação infantil: um estudo em seis capitais Brasileiras. Cadernos de Pesquisa, São Paulo, v. 41, n. 142, p. 20-54, abr. 2011.

CORSARO, William. A reprodução interpretativa no brincar ao "faz-de-conta" das crianças. Educação, Sociedade e Cultura: Revista da Associação de Sociologia e Antropologia da Educação, Porto, v. 17, p. 113-134, 2002.

COUTINHO, Ângela Scalabrin; MORO, Catarina; SOUZA, Gizele. A pesquisa em rede: marcas do percurso acerca da avaliação de contexto em Educação Infantil. In: SOUZA, Gizele; MORO, Catarina; COUTINHO, Ângela Scalabrin. Formação da rede em educação infantil: avaliação de contexto. Curitiba: Appris, 2015, p. 51-71.

CUSSIÁNOVICH, Alejandro. Participacion ciudadana de la infancia desde el Paradigma del protagonismo. In: CONGRESO MUNDIAL DE INFANCIA ADOLESCENCIA “CIUDADANIA DESDE LA NIÑEZ Y ADOLESCENCIA Y EXIGIBILIDAD DE SUS DERECHOS”, 2. Lima, Peru, 2005. [digitalizado]. Lima: Child Rights International Network, 2005, p. 1-29. Disponível em: http://www.crin.org/docs/Perú_Congress_ IFEJANT_Alenjandro_Cussianovish.doc. Acesso em: 2 dez. 2005.

DARDER, Pere; MESTRES, Joan. Autovalutazione dei servizi educativi per l'infanzia. Gusmini, Milano: FrancoAngeli, 2000

FERREIRA, Maria Manuela Martinho. Do “avesso” do brincar ou... as relações entre pares, as rotinas da cultura infantil e a construção da(s) ordem(ens) social(ais) instituintes(s) das crianças no Jardim-de-Infância. In: SARMENTO, Manoel Jacinto; CERISARA, Ana Beatriz. Crianças e miúdos: perspectivas sociopedagógicas da infância e educação. Porto: ASA, 2004, p. 55-104.

INSTITUIÇÃO DE EDUCAÇÃO INFANTIL. A avaliação da qualidade da brincadeira. Curitiba: Instituição de Educação Infantil, 2017 [digitalizado].

MORO, Catarina; COUTINHO, Ângela Scalabrin; BARBOSA, Etienne B. L. Avaliação de contexto em educação infantil: a participação e o protagonismo docente. ReLadEI: Revista Latino Americana de Educación Infantil, v. 6, n. 1, p. 23-37, enero/jun. 2017.

ORGANIZAÇÃO DAS NAÇÕES UNIDAS - ONU. Declaração Universal dos Direitos da Criança. 1989.

PIOTTO, Débora Cristina et al. Promoção da qualidade e avaliação na educação infantil: uma experiência. Cadernos de Pesquisa, São Paulo, n. 105, p. 52-77, nov. 1998.

SARMENTO, Manoel Jacinto; CERISARA, Ana Beatriz. Crianças e miúdos: perspectivas sociopedagógicas da infância e educação. Porto: ASA, 2004.

SAVIO, Donatella. Il gioco e l'identità educativa del nido d'infanzia: un percorso di valutazione formativa partecipata nei nidi di Modena, Bergamo. Azzano San Paolo (Bg): Edizioni Junior, 2011.

SAVIO, Donatella. A brincadeira e a participação da criança: um desafio educativo e seus pontos nodais. In: BONDIOLI, Anna; SAVIO, Donatella. Participação e qualidade em educação da infância: percursos de compartilhamento reflexivo em contextos educativos. Curitiba: Editora da UFPR, 2013a.

SAVIO, Donatella. La valutazione come "promozione dall'interno". ReLadEI - Revista Latino Americana de Educación Infantil, v. 2, n. 2, p. 70-85, jul./dic. 2013b.

SOUZA, Tatiana Noronha de; CAMPOS-DE-CARVALHO, Mara. Qualidade de ambientes de creches: uma escala de avaliação. Psicologia em Estudo, Maringá, v. 10, n. 1, p. 87-96, jan./abr. 2005.

SOUZA, Gizele; MORO, Catarina; COUTINHO, Ângela Scalabrin. Formação da rede em educação infantil: avaliação de contexto. Curitiba: Appris, 2015. 
SPRÉA, Nélio E. A invenção das brincadeiras: um estudo sobre a produção das culturas infantis nos recreios de escolas em Curitiba. 2010. 303 f. Dissertação (Mestrado em Educação) - Universidade Federal do Paraná, Curitiba, 2010

TAYLER, Collette. Avaliação da qualidade da educação infantil na Austrália. Estudos em Avaliação Educacional, São Paulo, v. 25, n. 58, p. 126-150, maio/ago. 2014.

VIEIRA, Daniele Marques. Imagens da experiência educativa de professores da educação infantil no espaço-ambiente do Proinfância. 2016. 228 f. Tese (Doutorado em Educação) - Universidade Federal do Paraná, Curitiba, 2016.

VIÑAO-FRAGO, Antonio; ESCOLANO, Agustín. Currículo, espaço e subjetividade: a arquitetura como programa. Rio de Janeiro: DP\&A, 1998.

ZABALZA, Miguel Antonio. Didáctica de la educación infantil. 5. ed. Madrid: Narcea, 2002.

ZUCOLOTO, Karla Aparecida. Educação infantil em creches: uma experiência com a escala ITERS-R. 2011. 307 f. Tese (Doutorado em Educação) - Universidade de São Paulo, São Paulo, 2011.

NOTE: The authors equally participated in the elaboration and revision of the article.

\section{HOW TO CITY THIS ARTICLE}

COUTINHO, Ângela Scalabrin; MORO, Catarina; VIEIRA, Daniele Marques. The evaluation of play quality in early childhood education. Cadernos de Pesquisa, São Paulo, v. 49, n. 174, p. 36-59, Oct./Dec. 2019.

https://doi.org/10.1590/198053146174 